\title{
Texture, hedonic test and fatty acid profile of goat cheese with L plantarum TW14 and $L$. rhamnosus TW2 isolates stored at different temperature conditions
}

\author{
T. Setyawardani*, K. Widayaka, J. Sumarmono, A. H. D. Rahardjo, S. S. Santoso and \\ M. Sulistyowati \\ Faculty of Animal Science, Universitas Jenderal Soedirman, \\ Jl. Dr. Soeparno No 60, Purwokerto 53123, Central Java - Indonesia \\ *Corresponding E-mail : trianaunsoed@gmail.com
}

Received October 29, 2017; Accepted July 10, 2018

\begin{abstract}
ABSTRAK
Penelitian bertujuan untuk mengetahui tekstur, kesukaan dan profil asam lemak kesukaan pada keju kambing yang disimpan dingin dan beku selama 60 hari. Starter yang digunakan berupa probiotik $L$ plantarum TW14 dan L rhamnosus TW2 rasio (1:1/v/v). Penelitian dilakukan dilakukan secara faktorial menggunakan dua faktor, sebagai faktor pertama adalah suhu (dingin; beku) dan sebagai faktor kedua adalah lama penyimpanan $(0 ; 15,30,45$ dan 60 hari) dan dilakukan 3 kali ulangan. Hasil penelitian memperlihatkan bahwa keju yang disimpan dalam refrigerator/suhu dingin mempunyai kekerasan tekstur rataan $374.46 \pm 77.69$ gf dan $221.66 \pm 38.46$ gf pada keju yang disimpan pada suhu beku dan berbeda sangat nyata $(\mathrm{P}<0.01)$. Kesukaan keju untuk atribut rasa, tekstur dan kesukaan keseluruhan tidak berbeda nyata baik suhu maupun, lama penyimpanan $(\mathrm{P}>0.05)$ tetapi untuk atribut aroma berbeda sangat nyata pada keju yang disimpan suhu yang berbeda $(\mathrm{P}<0.01)$. Keju yang disimpan selama 60 hari pada penyimpanan dingin menunjukkan asam lemak terbesar yaitu asam lemak jenuh Saturated Fatty Acids (SFA) dengan rataan $64.34 \%$ dan asam lemak tak jenuh Unsaturated Fatty Acids USFA) sebanyak $16.76 \%$. Selama penyimpanan 60 hari, persentase SFA relatif tetap sedangkan persentase USFA asam oleat meningkat.
\end{abstract}

Kata kunci : keju, suhu, kekerasan, sensori, asam lemak

\begin{abstract}
The purpose of this research was to investigate texture, hedonic test and fatty acids profile of goat cheese stored at cold and frozen temperatures for 60 days. Cheese was manufactured from goat milk with addition of probiotics bacteria L.plantarum TW14 and L.rhamnosus TW2 with a ratio of $(1: 1 / \mathrm{v} / \mathrm{v})$. Treatments were arranged in a factorial design, employing two factors, i.e. temperature (cold; frozen) and storage time $(0 ; 15,30,45$ and 60 days). Each treatment was repeated three times. Results showed that goat cheese stored at cold temperature has an average hardness-texture of $374.46 \pm 77.69$ gf while that of the cheese stored at frozen temperature has $221.66 \pm 38.46 \mathrm{gf}$, which were significantly different $(\mathrm{P}<0.05)$. In term of flavor, texture and overall acceptability, there were no significant effects $(\mathrm{P}>0.05)$ of storage temperatures and storage time. However, the taste of cheese stored under cold and frozen temperatures was highly significant different $(\mathrm{P}<0.01)$. Fatty acids composition of cheese stored for 60 days in a cold storage showed that the highest fatty acid content was SFA which was $64.34 \%$ and USFA was $16.76 \%$. During the 60 -day storage, the SFA percentage of was relatively stable while the
\end{abstract}


percentage of oleic acid USFA increased.

Keywords: cheese, temperature, hardness, hedonic, fatty acids

\section{INTRODUCTION}

Goat cheese is a type of cheese that is commonly developed in goat milk-producing countries in particular countries with year-round tropical climate (Ribeiro and Ribeiro, 2010). The development of goat cattle as milk producer in Indonesia has been widely practiced, because the goat milk has advantages compared to cow milk. Several advantages of goat milk are more medium level of fatty acid chains, more fatty globules with smaller diameter, and the softer curd produced from the goat milk, so that it is best used as a raw material for cheese (Park and Haenlein, 2013).

Probiotic is a group of bacteria that is beneficial to health, especially to digestive tract. A great number of studies have proven the benefits of probiotics for health and it is applied within functional food and drinks (Albenzio et al., 2015; Mushtaq et al., 2016; Aguilar-Toalá et al., 2017). Cheese is one of the best probiotics carrier according to several studies because cheese has a buffering capacity which plays a role in protecting probiotic bacteria in cheese matrix (da Cruz et al., 2009). L.plantarum TW14 and L.rhamnosus TW2 are two types of probiotic bacteria that come from goat milk (Setyawardani et.al., 2011) with characteristics of excellent probiotic, both in vitro and in vivo (Setyawardani et al., 2014) which are applied in cheese (Setyawardani et al., 2017).

Cheese is usually stored at room or cold temperature, whereas at cold temperature, cheese has longer shelf life compared to when it is stored at room temperature. During cold storage, the metabolism process goes more slowly so the changes go slowly, and the viability of probiotic LAB can still be maintained up till $10^{8} \mathrm{cfu} / \mathrm{g}$ for 30-day storage (Setyawardani and Sumarmono, 2015).

It is uncommon to store cheese at frozen temperature, however, storing cheese at frozen temperature is still needed for certain purposes, such as distributing cheese across regions/islands or countries which may take long delivery time (Kuo and Gunasekaran, 2009; Karimi et al., 2011). Frozen storage is needed to maintain cheese quality during a very long period of distribution and sales. Studies on frozen storage on cheese are still limited, possibly because as long as cheese is stored frozen, there is only insignificant change in cheese quality. On the other hand, there is a possibility of change quality in cheese stored in cold storage, which may lead to a decreased quality. When cheese is stored in frozen temperature, the ice matrix will be formed which influence the texture and chemical composition or LAB metabolism will change that allows cheese lipolysis and proteolysis process (Calzada et al., 2014; Juan et al., 2015; Bezerra et al., 2016). When cheese is stored cold or frozen, change in the texture occurs, in such that it will influence the physical characteristics and hardness. Furthermore, the fatty acid changes and cheese hedonic is also influenced by cheese storage. Fresh cheese would have a different hedonic level compared to previously frozen cheese. Therefore, the objectives of this research were to investigate texture, hedonic characteristics and fatty acids profile of goat cheese fatty acids with $L$ plantarum TW14 and L.rhamnosus TW2 isolates stored under cold and frozen temperature conditions.

\section{MATERIALS AND METHODS}

Goat milk was obtained from Etawah crossbred goats farm at Gumelar, Banyumas, Central Java. The milk was stored under a cold temperature until it was ready for use. The cheese manufactured from goat milk was stored at frozen and cold temperature, and it was stored for 0,15 , 30,45 and 60 days. Every treatment was repeated three times.

\section{Starter Preparation}

Starter preparation was done following the procedures described by Setyawardani et al. (2017) Two isolates, L.plantarum TW14 and L.rhamnosus TW2, were isolated from Etawah Crossbred goat milk (Setyawardani et al., 2011). One ose of isolates from each sample was taken and planted in De Man-Rogosa-Sharpe Broth (MRSB) media (Difco Laboratories, Michigan USA) then incubated for 24 hours at $37^{\circ} \mathrm{C}$ until ready to use.

\section{Cheese Manufacture}

Cheese manufacture was conducted 
according Setyawardani et al. (2017). The goat milk was pasteurized at $72^{\circ} \mathrm{C}$ for 15 seconds, and then cooled down to $37^{\circ} \mathrm{C}$. Starter, consisted of two isolates i.e. L.plantarum TW14 and L.rhamnosus TW2 of $5 \%$ with a ratio of $(1: 1) \mathrm{v} / \mathrm{v}$, was added, and the milk was incubated at $37^{\circ} \mathrm{C}$ until the milk pH decreased to about 6.1. Then, a total of $0.6 \mathrm{ml} / \mathrm{L}$ rennet was added, mixed thoroughly, and the milk was left undisturbed for two hours to allow coagulation. The curd or coagulum was cut and heated at $40^{\circ} \mathrm{C}$ for 10 minutes, continued with whey separation using cheese-cloth. The curd was pressed to complete the whey separation, and stored under cold and frozen temperatures.

\section{Cheese Texture}

The cheese hardness was rated using texture profile analysis (Buriti et.al, 2007) of TA-XT21 equipment (Stable Micro Systems, Haslmere, England). The cheese samples were cut into cylindrical form of $3.0 \mathrm{~cm}$ height and $2.4 \mathrm{~cm}$ diameter. The ready-for-test cheese was taken out of freezer/cold, and placed at room temperature for sample conditioning. The pressure ratio used was $20 \%$ from the height of initial sample at 2 $\mathrm{mm}$. The cheese hardness was rated using Texture Expert with Windows program 1.20.

\section{Hedonic Test}

Hedonic test was conducted by 30 semitrained panelists using 1 to 9 scale score sheet. Sensory parameters included taste, flavor, texture, and overall acceptability. The cheese samples were taken out of cold, cut out with the size of $1.5 \times 1.5 \times 1.5 \mathrm{~cm}$ (Ong et al., 2007). Sample evaluation was conducted with a scoring to evaluate the like and not-like level on attributes of taste, flavor, texture and overall acceptability. The previous samples which were adapted for 1 hour at room temperature were placed on a tray and each given a three-digit-number code. Coffee powder was provided to neutralize after sensory evaluation for flavor attribute. Members of the panel were asked to determine their level of hedonic on every cheese sample without comparing to other samples. The texture attribute was tested using hands to evaluate cheese texture.

\section{Measuring Fatty Acid with Gas Chromatography}

Fatty acids contents of cheese were determined following the procedures of AOAC
(2006). Analysis with gas chromatography was based on partition of components of fluid between the moving phases in terms of gas and static phase, in the form of solid and fluid which do not easily vaporize, attached on the inert supporting materials. The phases were started by hydrolyzing the fat into fatty acid, and then transformed it into an ester form which evaporates better. In this method, the transformation was conducted by way of methylation, until fatty acid ester methyl (FAME) was formed. Next, the FAME was analyzed using gas chromatography. Every component was identified by comparing its retention time against the standard on the same analysis condition. The retention time was calculated on a recorded paper as a distance from a line, when a solvent peak occurred till the center of the treated component peak. Determination of component content in the samples can be done with either external or internal standard technique. The area of each component is directly proportional to the total component in the sample. To minimize the error from injection volume, sample preparation, dilution, etc., it is better to use internal standard technique. In addition, the correction on detector response and interaction among components in the sample matrices must be conducted when it was passing the columns.

\section{Statistical Analysis}

The data collected, including quantified data of sensory evaluation, was presentated as means \pm standard deviation. Procedure of general linear model was employed, followed by Duncan's Multiple Range Test for means comparison.

\section{RESULTS AND DISCUSSIONS}

\section{Cheese Texture}

The cheese texture is among parameters of cheese physical qualities that influence consumers' acceptance. The cheese texture changed during storage, which was influenced by chemical composition, in particular fat in the dry matter and moisture in the nonfat substances (Zheng et al., 2016). Table 1 shows the effects of storage temperatures on cheese hardness.

The water content directly influences the firmness, higher water content creates a softer cheese texture and showed that there was an increase in proteolysis. In addition, the content of mineral and sodium in the cheese in the form of ionic will influence the texture (Guggisberg et al., 2017). The cheese stored for 60 days at cold 
Table 1. Cheese Goat Texture (hardness) Stored at Different Temperature for 60 Days of Storage (gf)

\begin{tabular}{lcccccc}
\hline \multirow{5}{*}{ Temperature } & \multicolumn{5}{c}{ Storage time (days) } & \multirow{2}{*}{ Average } \\
\cline { 2 - 6 } & 0 & 15 & 30 & 45 & 60 & \\
\hline Frozen & $275.95 \pm 9.82$ & $200.50 \pm 6.36$ & $196.30 \pm 4.94$ & $209.05 \pm 16.61$ & $226.50 \pm 66.60$ & $221.66 \pm 38.46^{\mathrm{a}}$ \\
Cold & $227.40 \pm 32.10$ & $373.20 \pm 43.41$ & $379.95 \pm 89.44$ & $368.30 \pm 67.88$ & $473.45 \pm 14.90$ & $374.46 \pm 77.69^{\mathrm{b}}$ \\
\hline
\end{tabular}

Different superscript in the same column show higly significantly different $(\mathrm{P}<0.01)$

temperature had a higher texture hardness, and there was a significant difference $(\mathrm{P}<0.01)$ compared to the cheese stored at frozen temperature. Length of storing did not influence the cheese hardness. Storing at cold temperature increased cheese hardness, since the water evaporated during the ripening (Delgado et al., 2011). Storing cheese at frozen temperature created a lower hardness compared to that of cheese texture stored at cold temperature. Ice crystals that got into cheese matrix during the frosting has weakened the bonds between proteins making the cheese texture softer and when the cheese was conditioned at room temperature before the rating began, the water was out/evaporated due to thawing process, therefore the cheese texture became softer. The low water content (the percentage of water in the material other than fat) is correlated with higher hardness and endurance, however, the springiness and cohesiveness of the cheese is lower (Zheng et.al, 2016). Proteolysis influences the establishment of flavor and off-flavor compound in the cheese, by releasing the peptide and free amino acids which thereafter a secondary reaction occurs. Splitting the protein tissue leads to a change of cheese matrix structure which will influence the resulting texture. (Delgado et al., 2011). The hardness of cheese texture at frozen storage was lower than that at cold storage could happen due to a decrease of phosphate calcium content during the formation of colloidal cheese due to low $\mathrm{pH}$, wherein $\mathrm{pH} 4.7$ would result in stable colloidal cheese (Diezhandino et al., 2016).

\section{Cheese Hedonic Test}

The cheese hedonic rated by the semi-trained panelists was flavor, aroma, texture, and overall cheese hedonic using a scoring scale (Table 2). Goat cheese stored at different temperatures and length storage time for 60 days has the level of cheese hedonic, texture and overall hedonic relatively similar $(\mathrm{P}>0.05)$, as rated by 25 semitrained panelists. The level of hedonic towards cheese flavor ranged between 4.96 and 6.64 (goaty - cheese flavor) The cheese texture received the scores between 4.92 and 6.20 (softhard chesse) while the scores for overall cheese hedonic were 4.40-7.04 (less preferred- like). The cheese produced had white color, a typical of color of goat cheese and had a fresh aroma. In addition to being influenced by LAB the cheese flavor and texture was also generated from several complex compound produced from the process of proteolysis, lipolysis, and glycolysis during the storing. The typical cheese flavor and aroma produced from lipolysis process, proteolysis and degradation further amino acid by starter culture and non-starter culture bacteria lactose acid. The proteolysis product contributed directly in the cheese flavor or acted as a precursor compound of cheese flavor. The cheese received aroma scores between 4.40 and 7.26 (goaty- cheese flavor) in which the cheese aroma stored in cold temperature had a higher average score and significantly different $(\mathrm{P}<0.01)$ compared to the cheese stored at frozen temperature. In cold storing, bacteria metabolism still occurred but slowly, therefore, the proteolysis and lipolysis process occurred slowly. In addition to the above, the enzyme produced by probiotic LAB could influence the biochemical process and might result in the cheese smell and aroma. The formation of cheese aroma and flavor was influenced by proteolysis process, which showed matrix casein hydrolysis in small peptide dissolved, and free amino acid which had a role on cheese sensory and texture. The above process was regulated by milk endogen enzyme, coagulants, and enzymes produced by starter and non-starter bacteria (Albenzio et al., 2013). The sour taste of cheese came from citric acid, the bitter taste came from quinine and the salty taste came from $\mathrm{NaCl}$ (Albenzio et al., 2013). Cheese 
Table 2. Hedonic Test Goat Cheese Stored at Different Temperatures for 60 Days of Storage (Score)

\begin{tabular}{lccccc}
\hline Temperature & $\begin{array}{c}\text { Storage time } \\
\text { (days) }\end{array}$ & Taste & Flavor & Texture & $\begin{array}{c}\text { Overall } \\
\text { preference }\end{array}$ \\
\hline Frozen & 0 & 4.96 & $4.76^{\mathrm{a}}$ & 5.08 & 4.40 \\
& 15 & 5.60 & $4.40^{\mathrm{a}}$ & 4.92 & 5.40 \\
& 30 & 5.32 & $4.92^{\mathrm{a}}$ & 5.28 & 5.20 \\
& 45 & 5.52 & $5.28^{\mathrm{a}}$ & 6.00 & 5.32 \\
& 60 & 5.00 & $5.32^{\mathrm{a}}$ & 5.60 & 5.52 \\
Cold & Average & 5.25 & 4.94 & 5.37 & 5.17 \\
& 0 & 4.68 & $7.28^{\mathrm{b}}$ & 6.00 & 5.72 \\
& 15 & 5.72 & $5.84^{\mathrm{b}}$ & 5.28 & 5.36 \\
& 30 & 6.64 & $6.48^{\mathrm{b}}$ & 6.72 & 7.04 \\
& 45 & 6.16 & $5.76^{\mathrm{b}}$ & 6.20 & 5.68 \\
& 60 & 5.08 & $5.00^{\mathrm{b}}$ & 5.32 & 5.16 \\
& Average & 5.65 & 6.07 & 5.90 & 5.79 \\
\hline
\end{tabular}

Different superscript in the same column show higly significantly different $(\mathrm{P}<0.01)$

texture stored at frozen received an average hedonic score of 4.94 , while the cheese stored at cold temperature received an average score of 6.07. The cheese texture stored at cold temperature is harder than the cheese stored at frozen temperature. The addition of probiotic $\mathrm{LAB}$ Lactobacillus casei resulted in cheese with low $\mathrm{pH}$ values and high proteolysis indexes, with rigidity tended to decrease during storage (Dantas et al., 2016). The above result is in accordance to the review on cheese texture hardness using texture profile analysis (TPA). The hardness on cheese was due to a low water content therefore making the cheese dryer on a lower $\mathrm{pH}$. Changes in $\mathrm{pH}$ and calcium concentration did not adversely affect the cheese's cohesive characteristic although there was a change of cheese hardness (Soodam et al., 2015). It has been reported that, biochemical changes during ripening contributed to the changes in textural characteristics of cheese (Andronoiu et al., 2015).

The overall hedonic towards the cheese was an average score of 4.40-7.04 ((less preferredlike)) different treatment of temperature and storing did not influence cheese hedonic $(\mathrm{P}>0.05)$. Hedonic towards a product is consumer assessment which is influenced by several attributes which contribute to the hedonic, among others: the sense of taste used to taste flavor and the sense of smell to rate the cheese aroma, and the skin to feel the cheese texture.

\section{Fatty Acid Profiles}

The best result of cheese texture hardness and the test hedonic of aroma attribute by the panelists was the goat cheese stored at cold temperature which was stored for 60 days. Fatty acid profiles from the best result was then analyzed using a gas chromatography. Fatty acids in the identified cheese was the cheese stored at cold temperature, according to the result of physical quality and the level of consumer hedonic. The profile result of cheese fatty acids showed 26 types of fatty acids, in which the said fatty acids were dominated by palmitic fatty acid (C16:0) for saturated fatty acid and oleic fatty acid $(\mathrm{C} 18: \ln 9 \mathrm{c})$ for 60 days storage (Table 3 ).

Oleic acid belongs to acid group with the highest amount of acid and carries a characteristic of mammal milk. (Butler et al., 2011; Mayer and Fiechter, 2012). During cheese storing, there was the same of tendency in the short, medium and long chain fatty acid group (Figure 1). The general average for the 60-day storage was the fatty acid with $\mathrm{C} 2-6$ of $3.77 \%$, chain $\mathrm{C} 7-11$ of $9.98 \%$ and chain $\geq 12$ of $70.88 \%$.

Research data on cheese stored for 60 days at cold storage showed that the highest fatty acid was SFA i.e. an average of $64.34 \%$ and USFA of $16.76 \%$. During the 60-day storage, the SFA 
Table 3. Fatty Acids Profile of Goat Cheese Stored at Cold Temperature for 60 Days (\%)

\begin{tabular}{|c|c|c|c|c|c|}
\hline \multirow{2}{*}{ Fatty Acids } & \multicolumn{5}{|c|}{ Storage Time (days) } \\
\hline & 0 & 15 & 30 & 45 & 60 \\
\hline Fat total & 23.53 & 26.76 & 27.91 & 27.39 & 28.50 \\
\hline Caproic Acid, C6:0 & 4.74 & 4.16 & 3,39 & 1,61 & 1,46 \\
\hline Caprilic Acid, C8:0 & 1.60 & 1.96 & 1.91 & 2.08 & 1.67 \\
\hline Capric Acid, C10:0 & 5.23 & 6.84 & 6.72 & 6.79 & 5.33 \\
\hline Undecanoic Acid, C11:0 & 0.05 & 0.06 & 0.06 & 0.04 & 0.04 \\
\hline Lauric Acid, C12:0 & 1.89 & 2.80 & 2.80 & 2.39 & 1.87 \\
\hline Tridecanoic Acid, C13:0 & 0.04 & 0.05 & 0.05 & 0.05 & 0.04 \\
\hline Myristic Acid, C14:0 & 5.24 & 6.16 & 6.13 & 5.84 & 5.15 \\
\hline Myristoleic Acid, C14:1 & 0.06 & 0.08 & 0.09 & 0.05 & 0.05 \\
\hline Pentadecanoic Acid, C15:0 & 0.62 & 0.55 & 0.55 & 0.67 & 0.70 \\
\hline Palmitic Acid, C16:0 & 18.15 & 19.15 & 19.77 & 18.40 & 18.56 \\
\hline Palmitoleic Acid, C16:1 & 0.63 & 0.72 & 0.73 & 0.61 & 0.70 \\
\hline Heptadecanoic Acid, C17:0 & 0.57 & 0.52 & 0.55 & 0.71 & 0.77 \\
\hline Stearic Acid, C18:0 & 13.20 & 11.17 & 11.60 & 12.77 & 13.71 \\
\hline Elaidic Acid, C18:1n9t & 3.89 & 2.47 & 2.39 & 2.86 & 2.41 \\
\hline Oleic Acid, C18:1n9c & 22.12 & 20.11 & 21.61 & 20.67 & 24.54 \\
\hline Linolelaidic Acid,C18:2n9t & 0.20 & 0.16 & 0.17 & 0.15 & 0.16 \\
\hline Linoleic Acid, C18:2n6c & 3.24 & 2.53 & 2.81 & 2.28 & 2.42 \\
\hline Arachidic Acid, C20:0 & 0.18 & 0.17 & 0.17 & 0.15 & 0.18 \\
\hline Cis-11-Eicosenoic Acid, C20:1 & 0.58 & 0.47 & 0.51 & 0.72 & 0.71 \\
\hline Heneicosanoic Acid, C21:0 & 0.06 & 0.05 & 0.05 & 0.07 & 0.07 \\
\hline Cis-11,14-Eicosedienoic Acid, C20:2 & 0.05 & 0.04 & 0.04 & 0.04 & 0.05 \\
\hline Behenic Acid, C22:0 & 0.06 & 0.05 & 0.05 & 0.06 & 0.06 \\
\hline Arachidonic Acid, C20:4n6 & 0.14 & 0.15 & 0.16 & 0.13 & 0.13 \\
\hline Lignoceric Acid, C24:0 & 0.03 & 0.02 & 0.02 & 0.04 & 0.03 \\
\hline $\begin{array}{l}\text { Cis-5,8,11,14,17-Eicosapentaenoic } \\
\text { Acid, C20:5n3 }\end{array}$ & 0.04 & 0.03 & 0.04 & 0.06 & 0.08 \\
\hline $\begin{array}{l}\text { Cis- } 4,7,10,13,16,19- \\
\text { Docosahexaenoic Acid, C22:6n3 }\end{array}$ & 0.02 & 0.03 & 0.03 & 0.04 & 0.04 \\
\hline Total fatty acids & 82.64 & 80.48 & 82.41 & 79.27 & 80.94 \\
\hline
\end{tabular}

percentage was relatively stable while the percentage of oleic acid USFA increased. The composition of fatty acids significantly determines the resulting fat, in which its characteristic depends on the length of carbon chain, the number of unsaturated bonds, whether it is of cis or trans geometrical configuration (Markiewicz-Kęszycka et al., 2013).
The content of monounsaturated fatty acid (MUFA) in the cheese stored for 60 days was relatively lower, i.e. C14:1 of 0.05-0.09\%; C16:1 of $(0.61-0.73 \%)$, this fatty acid contributed as precursor of CLA formation (MarkiewiczKęszycka et al., 2013). MUFA did not cause a build up of cholesterol as in SFA, and neither did it create rancid smell as in PUFA. MUFA had a 


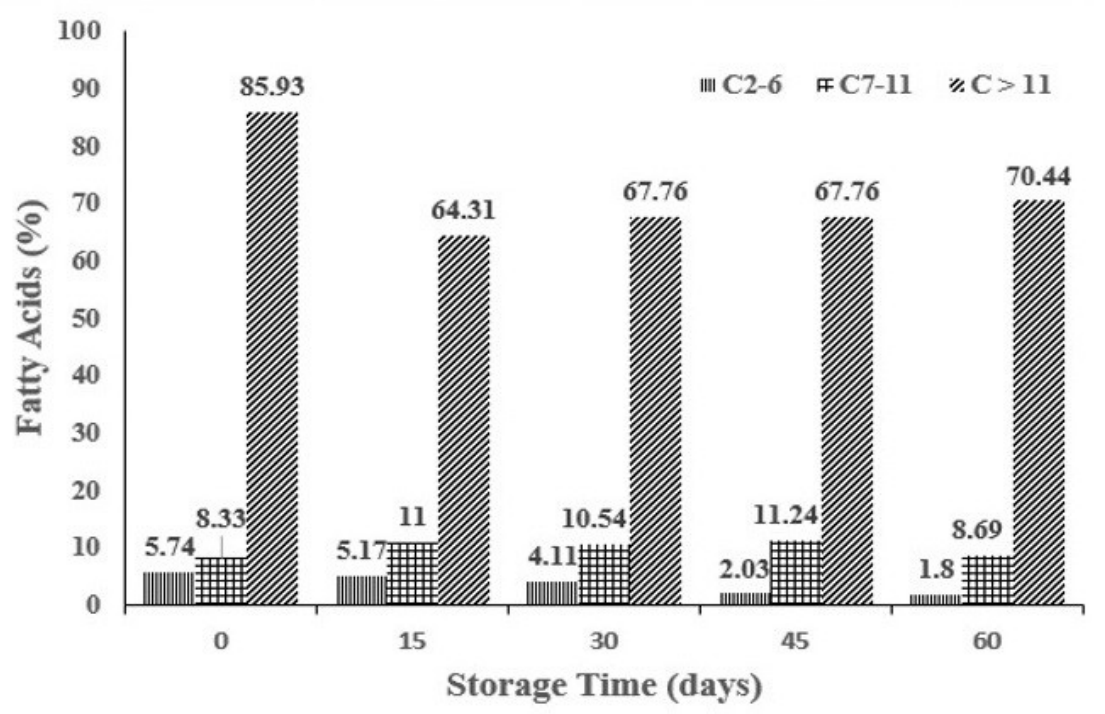

Figure 1. Percentage of Short, Medium and Long Chains Fatty Acids Cheese Kept at Cold Storage Up to 60 Days

positive effect on the controlling High-Density Lipoprotein (HDL), which acted to transport cholesterol from blood vessel wall to liver, which would be degraded by bile acids, then taken out. At the same time, MUFA would lower LDL concentration (Markiewicz-Kęszycka et al., 2013).

\section{CONCLUSION}

The hardness of cheese stored in cold temperature was higher than the cheese stored at frozen temperature, and this is in accordance with the rate on texture hedonic by sensory. The highest proportion of cheese fatty acid stored at cold temperature for 60 days was SFA with an average of $64.34 \%$ and USFA of $16.76 \%$, in which USFA was dominated by oleic acids and was a characteristic of mammal milk. Therefore, it is recommended to store probiotic-containing cheese under cold temperature for 60 days due to its texture and fatty acid profile.

\section{ACKNOWLEDGEMENTS}

This study was funded by the Directorate General of Higher Education for the grant through National Strategic scheme in the year of 2015, grant number 2411/UN/23.10.

\section{REFERENCES}

Aguilar-Toalá, J., L. Santiago-López, C. Peres, C.
Peres, H. Garcia, B. Vallejo-Cordoba, A. Gonzalez-Cordova and A. HernándezMendoza. 2017. Assessment of multifunctional activity of bioactive peptides derived from fermented milk by specific Lactobacillus plantarum strains. J. Dairy Sci. 100: 65-75.

Albenzio, M., A. Santillo, M. Caroprese, A. Braghieri, A. Sevi and F. Napolitano. 2013. Composition and sensory profiling of probiotic Scamorza ewe milk cheese. J. Dairy Sci. 96: 2792-2800.

Albenzio, M., A. Santillo, R. Marino, A. Della Malva, M. Caroprese and A. Sevi. 2015. Identification of peptides in functional Scamorza ovine milk cheese. J. Dairy Sci. 98:8428-8432.

Andronoiu, D. G., E. Botez, O. V. Nistor and G. D. Mocanu. 2015. Ripening process of Cascaval cheese: compositional and textural aspects. J Food Sci. Technol. 52: 5278-5284.

AOAC. 2006. Official Method of Analysis. $15^{\text {th }}$ Ed. Association of Official Analytical Chemists Inc., Virginia USA.

Bezerra, T. K. A., A. R. R. de Araujo, E. S. do Nascimento, J. E. de Matos Paz, C. A. Gadelha, T. S. Gadelha, M. T. B. Pacheco, R. d. C. R. do Egypto, M. E. G. de Oliveira and M. S. Madruga. 2016. Proteolysis in goat "coalho" cheese supplemented with probiotic lactic acid bacteria. Food Chem. 196:359-366.

Butler, G., S. Stergiadis, C. Seal, M. Eyre and C. 
Leifert. 2011. Fat composition of organic and conventional retail milk in northeast England. J. Dairy Sci. 94:24-36.

Calzada, J., A. del Olmo, A. Picon, P. Gaya and M. Nuñez. 2014. Effect of high-pressureprocessing on the microbiology, proteolysis, texture and flavour of Brie cheese during ripening and refrigerated storage. Int. Dairy J. 37:64-73.

da Cruz, A. G., F. C. A. Buriti, C. H. B. de Souza, J. A. F. Faria and S. M. I. Saad. 2009. Probiotic cheese: health benefits, technological and stability aspects. Trends Food Sci. Technol. 20:344-354.

Dantas, A. B., V. F. Jesus, R. Silva, C. N. Almada, E. Esmerino, L. P. Cappato, M. C. Silva, R. S. Raices, R. N. Cavalcanti and C. C. Carvalho. 2016. Manufacture of probiotic Minas Frescal cheese with Lactobacillus casei Zhang. J. Dairy Sci. 99: 18-30.

Delgado, F. J., J. González-Crespo, R. Cava and R. Ramírez. 2011. Proteolysis, texture and colour of a raw goat milk cheese throughout the maturation. Eur. Food Res. Technol. 233: 483-488.

Diezhandino, I., D. Fernández, N. Sacristán, P. Combarros-Fuertes, B. Prieto and J. Fresno. 2016. Rheological, textural, colour and sensory characteristics of a Spanish blue cheese (Valdeón cheese). LWT-Food Sci. Technol. 65:1118-1125.

Guggisberg, D., H. Winkler, U. Bütikofer, M.-T. Fröhlich-Wyder, L. Egger, R. Badertscher and D. Wechsler. 2017. Influence of chemical and biochemical characteristics on the texture of Appenzeller ${ }^{\circledR}$ cheese. Int. Dairy J. 75:111-119.

Juan, B., J. M. Quevedo, A. Zamora, B. Guamis and A.-J. Trujillo. 2015. Lipolysis of cheeses made from goat milk treated by ultra-high pressure homogenization. LWT-Food Sci. Technol. 60:1034-1038.

Karimi, R., A. M. Mortazavian and A. G. Da Cruz. 2011. Viability of probiotic microorganisms in cheese during production and storage: a review. Dairy Sci. Technol. 91:283-308.

Kuo, M.-I. and S. Gunasekaran. 2009. Effect of freezing and frozen storage on microstructure of Mozzarella and pizza cheeses. LWT-Food Sci. Technol. 42:9-16.

Markiewicz-Kęszycka, M., G. Czyżak-Runowska,
P. Lipińska and J. Wójtowski. 2013. Fatty acid profile of milk-a review. Bull. Vet. Inst. Pulawy 57:135-139.

Mayer, H. K. and G. Fiechter. 2012. Physical and chemical characteristics of sheep and goat milk in Austria. Int. Dairy J. 24:57-63.

Mushtaq, M., A. Gani, F. Masoodi and M. Ahmad. 2016. Himalayan cheese (Kalari/Kradi)-Effect of different probiotic strains on oxidative stability, microbiological, sensory and nutraceutical properties during storage. LWT-Food Sci. Technol. 67:74-81.

Park, Y. W. and G. F. W Haenlein (eds). 2013. Milk and dairy products in human nutrition: production, composition and health. John Wiley \& Sons, Oxford UK.

Ribeiro, A.C. And S.D.A. Ribeiro. 2010. Speciality product made from goat milk. Small Rum. Res. 89(2-3):225-233.

Setyawardani, T., A. H. Rahardjo, M. Sulistyowati and S. Wasito. 2014. Physiochemical and Organoleptic Features of Goat Milk Kefir Made of Different Kefir Grain Concentration on Controlled Fermentation. J. Anim. Prod. 16: 48-54.

Setyawardani, T., A. H. D. Rahardjo and M. Sulistyowati. 2017. Chemical Characteristics of Goat Cheese with Different Percentages of Mixed Indigenous Probiotic Culture during Ripening. Med. Pet. 40:55-62.

Setyawardani, T., W. Rahayu, R. Maheswari and N. Palupi. 2011. Identification and characterization of probiotic lactic acid bacteria isolated from indigenous goat milk. J. Anim. Prod. 13:57-63.

Setyawardani, T. and J. Sumarmono. 2015. Chemical and Microbiological Characteristics of Goat Milk Kefir During Storage under Different Temperatures. J. Indonesian Trop. Anim. Agric. 40:183-188.

Soodam, K., L. Ong, I. B. Powell, S. E. Kentish and S. L. Gras. 2015. Effect of calcium chloride addition and draining $\mathrm{pH}$ on the microstructure and texture of full fat Cheddar cheese during ripening. Food Chem. 181:111-118.

Zheng, Y., Z. Liu and B. Mo. 2016. Texture Profile Analysis of Sliced Cheese in relation to Chemical Composition and Storage Temperature. J. Chem. 2016:1-10 